\title{
SEDIMENTARY TRANSPORT IN COASTAL BAYS: CASE STUDY OF VITÓRIA AND ESPÍRITO SANTO BAYS - ES - BRAZIL
}

\author{
Rafael C. Neves ${ }^{1,2}$, Valéria da S. Quaresma ${ }^{1}$, Alex C. Bastos ${ }^{1}$ and Júlio C.R. da Silva ${ }^{3}$ \\ Recebido em 24 maio, 2011 / Aceito em 28 dezembro, 2011 \\ Received on May 24, 2011 / Accepted on December 28, 2011
}

\begin{abstract}
Coastal sediment dynamics is strongly influenced by distinct agents such as waves, currents, tides and wind. Sediment transport pattern is associated to the prevailing forcing mechanisms which will be typical for each study area. This investigation has collected and analyzed in situ hydrodynamics data (using an ADP - Nortek AS Aquadopp (2 MHz)) at two distinct sites along the Vitória coastal area. Results have shown a significant difference in hydrodynamics and associated induced sediment transport patterns. Espírito Santo Bay showed a quite complex circulation pattern associated to the influence of cold front systems, being dominated by storm waves that resuspend sediments that are swept away by the combined action of currents and waves. Vitória Bay, on the contrary, is dominated by tidal currents, with a strong ebb-dominated asymmetry. The results have shown that net transport direction is towards the mouth of the bay, indicating sediment export within this system.
\end{abstract}

Keywords: hydrodynamics, sediment transport, Vitória Bay.

RESUMO. A dinâmica sedimentar na região costeira é influenciada por diversos fatores como ondas, correntes, marés e vento. 0 padrão de transporte e domínio de cada processo será definido pelas características de cada área estudada. Através da coleta e análise de dados hidrodinâmicos a partir do fundeio de um ADP - Nortek AS Aquadopp (2 MHz), em dois pontos distintos da região costeira de Vitória, foi observado uma diferença marcante de comportamento hidrodinâmico no sistema. A Baía do Espírito Santo mostrou uma grande complexidade na circulação devido à influência de várias forçantes, principalmente ondas geradas pela passagem de frentes frias. Na Baía de Vitória, por outro lado, observa-se o domínio das correntes de maré. Dessa forma, os dados medidos e modelados de transporte de sedimento indicam esta complexidade. Na Baía do Espírito Santo observa-se o domínio de ondas de tempestade que controlam o processo de ressuspensão de sedimento que depois é transportado pela ação integrada das ondas e correntes. Na Baía de Vitória, o transporte de material particulado em suspensão e por carga de fundo é induzido diretamente pelo padrão das correntes de maré, principalmente, de maré vazante, mostrando uma tendência de exportação de sedimento neste sistema.

Palavras-chave: hidrodinâmica, transporte de sedimento, Baía de Vitória.

\footnotetext{
${ }_{1}$ Labogeo/UFES - Geological Oceanography Laboratory, Department of Oceanography and Ecology, Universidade Federal do Espírito Santo, Av. Fernando Ferrari, 516 Goiabeiras, 29600-075 Vitória, ES, Brazil. Phone: +55 (27) 4009-2878; Fax: +55 (27) 4009-2500 - E-mails: rafaeloceanografia@yahoo.com.br; valeria.quaresma@ufes.br; vdsq@terra.com.br; valeria@dern.ufes.br; alex.bastos@ufes.br

2UMISAN - Hidrografia e Engenharia, Rua Henrique Novaes, 88, sls. 407-409, Centro, 29010-490 Vitória, ES, Brazil. Phone: +55 (27) 3211-1293; Fax: +55 (27) 3222-8599 - E-mail: rafaeloceanografia@yahoo.com.br

3JRUANO Consultoria e Serviços Ltda. - ENVIRONLINK, Rua Santa Rita de Cássia, 229, sls. 101-103, Bairro de Lourdes, 29042-751 Vitória, ES, Brazil. Phone/Fax/Mobile: +55 (27) 3323-6950 / 3322-2202 / 9239-2870 - E-mail: julio@environlink.com.br
} 


\section{INTRODUCTION}

The coastal region is globally the most populated area, where there are many economical activities such as shipping, fishing, tourism, recreation activities and others. Due to the enormous importance of these areas in respect to the environmental, economical and social aspects, the knowledge and analysis of the mechanisms actuating in these regions are crucial for the correct handling and mitigation of possible impacts caused by its occupation.

The marine region near the coast has a very complex dynamics due to the joined interaction of waves, tides, coastal currents and atmospheric forcing. These factors hinder the understanding of the actuating processes in these regions (Martins et al., 2004). In the coastal regions, the tide flow and reflow cause constant changes in the ocean level, originating the tidal currents which are influenced by the amplitude and local geomorphology and the tidal asymmetry that may occur in these regions (as estuaries, for example). This asymmetry is related to the nonlinearity of the harmonics forming the astronomical tide (Speer \& Aubrey, 1985; Dyer, 1997). In relatively deep estuaries, with large water storage between tides, the ebb tide currents tend to have larger velocities, as a consequence of the fast water exchange between tidal flats and channels during ebb tide and the large friction during flood tide (Dronkers, 1986). The presence of tidal flats and mangroves or salt marshes in the coastal region also contributes to the existence of the differences between the velocities of the flood and ebb currents, due to the friction exerted by the smaller depth and vegetation (Wolanski et al., 1980, 1990; Mazda et al., 1995; Wang et al., 2002; Rigo, 2004; Fortunato \& Oliveira, 2005).

According to some authors (Van Rijn, 1993; Soulsby, 1997; Paphitis \& Collins, 2005), the direct action of the waves in the bottom is the most important mechanism for sediment resuspension, mainly, during the occurrence of storms. Many other natural and anthropogenic factors contribute to keep the suspended particulate matter (SPM), as the fluvial and eolian input, the coast erosion, dredging and fishing activity (Paphitis \& Collins, 2005). However, the physical processes that take place next to the bottom have more significance in terms of sediment transport, where, through the boundary layer, a friction force is exerted by waves and currents in the bottom, generating the sediment transport, once the threshold velocity of the grain movement is exceeded.

Modeling has been a good tool to quantify the preferential direction of the sediment transport, mainly because of the great difficulty to reach conclusions about the sediment transport, in spatial and temporal scale, by means of traditional indicators, such as the granulometric trends. Among the multiple models of sediment transport available, the SEDTRANS05 model, chosen in this work, has been used in many studies, such as Li et al. (1997) and Bastos et al. (2004).

Thus, taking into account the occupation process and the economical and environmental importance of the coastal region of the metropolitan area of Vitória, in Espírito Santo State, Brazil a study of the local hydrodynamics and the natural forcing that causes the sediment resuspension and transport is fundamentally important to understand the sediment mobilization events, contributing to the understanding of the physical processes acting in the region. The purpose of this work is to investigate the different forcing mechanisms that determine the sediment transport in the two bays that form the coastal region of the metropolitan area of Vitória.

\section{Study area}

This study was carried out in an estuarine system, located at the central region of Espírito Santo State, encompassing Vitória Bay (BV - Baía de Vitória) and Espírito Santo Bay (BES - Baía do Espírito Santo) (Fig. 1). BV presents two channels that allow its permanent connection with BES: Passagem Channel and Porto de Vitória Channel. Five rivers drain into BV. Santa Maria da Vitória river (RSMV - Rio Santa Maria da Vitória) is considered a medium-sized river and Bubu, Itanguá, Aribiri and Marinho rivers are considered small-sized rivers. The main fluvial input in this estuarine system takes place in Santa Maria da Vitória river (RSMV) (Veronez Jr et al., 2009).

Vitória coastal region is very complex due to the presence of many different environments, such as estuaries, channels and embayments. The local tide is classified as semidiurnal microtide, with heights less than $2 \mathrm{~m}$ and diurnal differences (Rigo, 2004).

The fluvial input and the coastal protection from the ocean wave action, ensures estuarine circulation conditions inside BV. According to the classification of estuaries provided by Fairbridge (1980), BV is a "coastal plain estuary", formed by the river valley flooding as a consequence of the sea level rise throughout the Holocene. The sediment cover is mainly mud, with sand on the bay narrowings, near the mouth of the RSMV (forming a bay head delta) and next to the estuary mouth (Veronez Jr et al., 2009). The large mangrove area (>2000 ha) on the margins of BV seems to influence fundamentally BV circulation, as shown by the circulation models (Donatelli, 1998; Rigo, 2004).

$\mathrm{BES}$ is more exposed to the ocean wave and wind action. Due to the regional wind pattern, the incident fair-weather waves are mainly from NE. They are less energetic and more refracted and dissipated at the entrance of BES (Albino et al., 2001). However, during the passage of cold fronts, S-SE waves, much more energetic, arrive in the region practically with no dissipation, due to SE orientation of the entrance of BES. Besides, this bay presents 


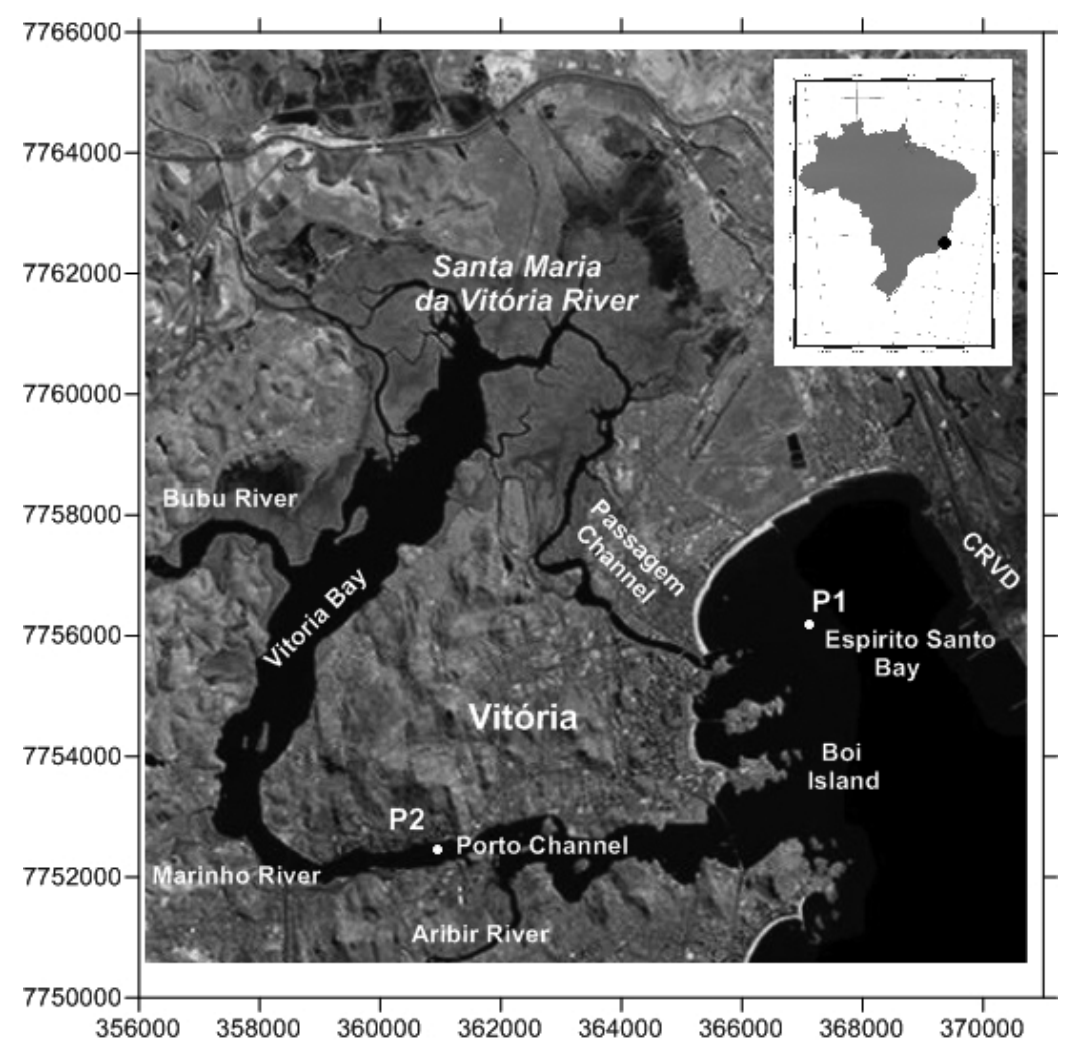

Figure 1 - Map of the estuarine system complex formed by Espírito Santo Bay and Vitória Bay. P1 and P2 are the ADP mooring sites, in Espírito Santo Bay and in Vitória Bay, respectively.

moderate to low bottom gradient with bottom sediments varying from mud, to coarse sand in the central region of the bay and next to llha do Boi (an island inside BES) (Carmo, 2009).

\section{METHODOLOGY}

\section{Hydrodynamics and turbidity data (SPM)}

The acquisition of the hydrodynamics data at the two study sites (Fig. 1) occurred during two different periods. The deployment in BES (P1) was carried out from June 15 to July 11, 2008 (26 days) and in BV (P2) from June 04 to June 19, 2009 (15 days). P1 (BES) is over a sandy seabed at $6 \mathrm{~m}$ of water depth and P2 (BV) is over a muddy seabed at $11 \mathrm{~m}$ of water depth.

The moorings used a structure with an Acoustic Doppler Profile (ADP) - Nortek AS Aquadopp (2 MHz), an optical backscatter sensor (OBS Campbell Scientific), located $20 \mathrm{~cm}$ above the bottom to measure the turbidity. The current data collection was carried out in $50 \mathrm{~cm}$ cells during 5 minutes with 30 minute intervals at the same OBS height. The wave data were sampled at a rate of $2 \mathrm{~Hz}$, for every 60 minute intervals. The turbidity optical sensor (OBS) data in BES and BV were not calibrated and the results are presented here in counts. In P1 (BES), the optical sensor was covered by encrusting organisms at hour 480 hour and, from this moment, the OBS readings were no longer considered.

The wave orbital velocity in BES was calculated for shallow water according to Soulsby (1997):

$$
U w=\frac{\pi H}{\mathrm{~T} \sinh (k h)}
$$

where $H$ is the wave height, T the wave period, $k=2 \pi / L$ the wave number, $L$ the wave length and $h$ the water column depth.

\section{Quantification and identification of the sediment trans- port direction next to the bottom}

The bedload sediment transport was calculated using the SEDTRANS05 model. This is a $1 \mathrm{D}$ computational numeric model written in FORTRAN77 to calculate the cohesive and non-cohesive sediment transports caused by the wave and current action or by the current action alone (Neumeier et al., 2008). The program offers five algorithm options for non-cohesive sediment transport, based on the equations of Brown (1950), Bagnold (1963), Yalin (1963), Engelund \& Hansen (1967), and Van Rijn (1993). Besides, due to the intensive complexity of the physical processes 
that involve the interaction between the fluid flow and sedimentary particles, the following data are also necessary: water column depth; current velocity and direction; significant wave height, wave period and direction; grain size, height and length of bedforms; bottom gradient; sediment specific mass; salinity and temperature of water (Neumeier et al., 2008).

The equation used in this work to quantify the sediment transport close to the bottom was the equation of Van Rijn (1993) that estimates more accurately the bedload transport rate for finer sands, as in the case of BES. Besides, Van Rijn method is considered the best indicated for current dominated environments (Neumeier et al., 2008), as in the case of BV. Van Rijn method follows Bagnold and assumes that the motion of the bottom particles is dominated by grain saltation under the influence of the flow and gravity forces.

The input data used, related to depth, current and wave, were measured by the equipments deployed at the two mooring sites. The salinity used for P1 in BES was 30 and for P2 in BV was 25. The specific mass of quartz (i.e. $2650 \mathrm{~kg} / \mathrm{m}^{3}$ ) was the one chosen. Besides, the bottom was considered flat with no bottom forms. The grain size at the mooring sites were obtained from the studies of Veronez Jr et al. (2009) and Carmo (2009) for BV (0.062 mm) and BES $(0.25 \mathrm{~mm})$, respectively.

The model SEDTRANS05 was used to estimate the sediment transport rates and direction, always relating the results to the local dynamics. The bottom mobility was examined in relation to the joined action of wave and current at P1 (BES) and P2 (BV). At P1 fair-weather and storm waves were observed during the acquisition period.

\section{RESULTS AND DISCUSSION}

\section{Hydrodynamics and transport of SPM and bedload at P1 (BES)}

The data show a complex circulation pattern in BES, as we can observe in Figure 2. In this place, there is not a clear variation pattern of velocity and current direction along the water column, during the tidal cycle. Probably, this fact is related to its geomorphological configuration. However, the influence of other forcing variables, such as wind-waves, swell and rip currents, is observed (local visual observation), establishing a small magnitude increase of the surface currents, on the order of $0.15 \mathrm{~m} / \mathrm{s}$, during the passage of cold fronts. During these periods, as it is expected, an increase of the height and orbital velocity of the waves is also observed, mainly between the hours 300 and 400 . During these moments the surface currents are chiefly orientated to the coast (Figs. 2a, b and 3b, c, d). This pattern is associated to the angle of entrance of the storm waves (S-SE quadrant). These waves enter the bay without dissipation or refraction due to the southeastward orientation of the entrance of BES.

During the measurements carried out for this study it was noticed that the significant wave heights were not higher than $1 \mathrm{~m}$ in fair-weather periods, but they were higher than $2 \mathrm{~m}$ during the more energetic events related to the passages of cold fronts (Fig. 3c). Consequently, this fact produced an increase of the orbital velocity of the waves followed by the resuspension of the bottom particulate matter. This is evidenced by the increase of the recorded turbidity values (around 60000 counts) (Figs. $3 d, e, g, h)$. In microtidal regions, as in BES, the chief natural mechanism for sediment resuspension is the wave action, mainly in storm events (Pepper \& Stone, 2004). Thus, during the passage of cold fronts, the sediment remobilization and transport potential in BES increases as a function of the combined effect of waves and currents. An evidence of this behavior in BES is that current velocity changes near the bottom was not observed during the entire period of measurements, even with storm events (Figs. $2 a$ and $3 b$ ), indicating that the remobilization process in the area is directly related to the increase of wave height and energy during the passage of cold fronts. From the resuspension, SPM is transported by the unidirectional component of the flow.

The passage of cold fronts in the area also interferes in the bedload transport. As we can observe in Figure 3f, an increase of the sediment transport rate in periods with greater orbital velocity of the waves is evident. As it was discussed in Van Rijn (1993), Soulsby (1997) and Paphitis \& Collins (2005), the waves suspend the material to be transported by the currents. However, in the absence of more energetic waves, the bedload transport calculated by SEDTRANS05 is almost zero (Fig. 3f).

The importance of the storm events for the bedload transport in the area can also be established through the comparison among the transport direction and the resulting transport rate for the entire study period, which were respectively $150^{\circ}$ and $6.2 \times$ $10^{-7} \mathrm{~kg} / \mathrm{s} / \mathrm{m}$, and for the days during passages of cold fronts, which were respectively $345^{\circ}$ and $3.4 \times 10^{-5} \mathrm{~kg} / \mathrm{s} / \mathrm{m}$. A clear increase of the transport rate during the cold front periods can be observed (Figs. 3f, g).

\section{Hydrodynamics and transport of SPM and bedload at P2 (BV)}

Tide is the forcing variable that has the largest influence on the circulation at P2 (BV) (Fig. 4). During the entire period of mea- 

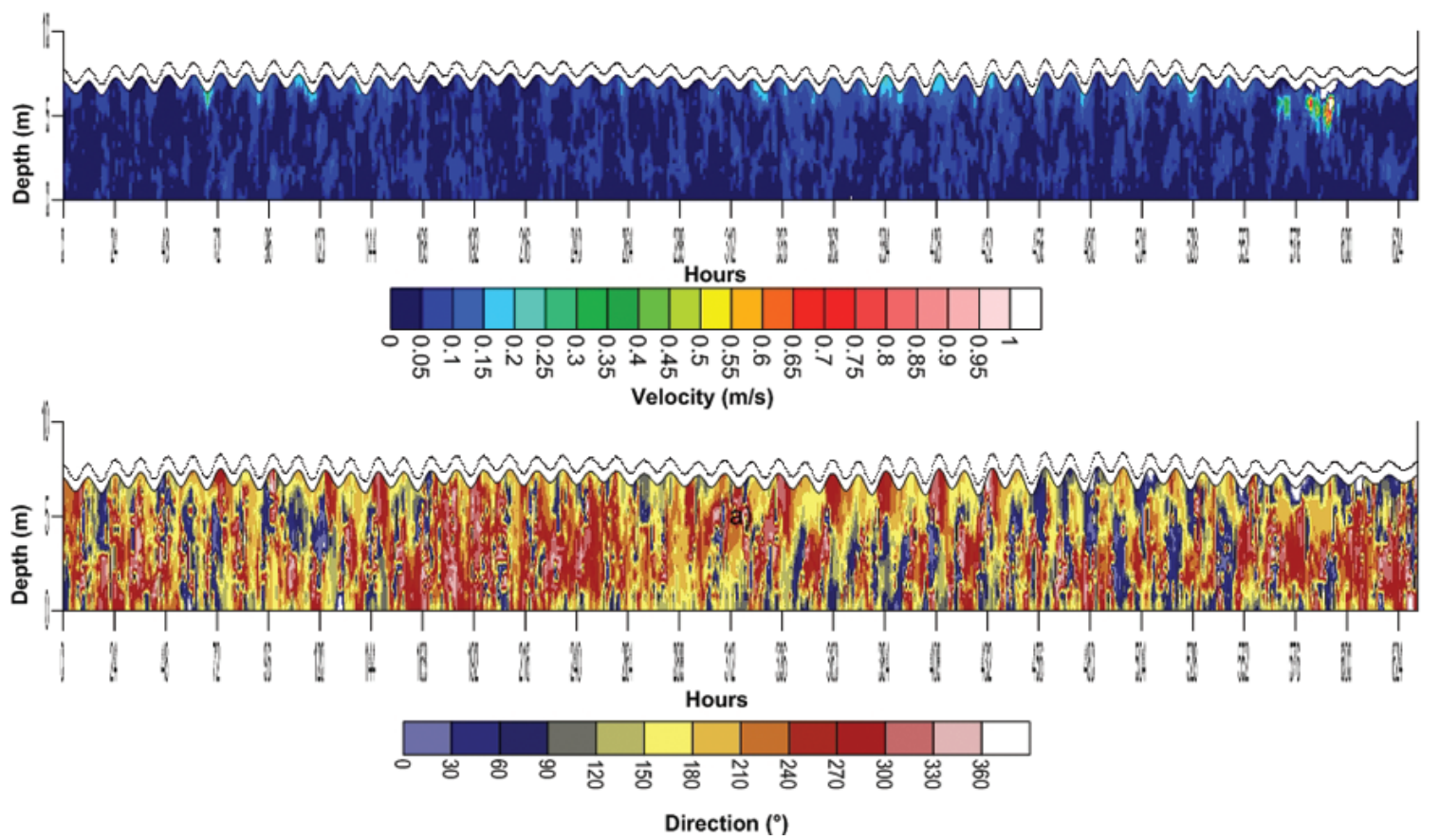

Figure 2 - Currents temporal series at P1 in Espírito Santo Bay: a) velocity; b) direction.

surements, it was noticed that ebb tides are the prevailing tides in terms of magnitude (around $0.5 \mathrm{~m} / \mathrm{s}$ more intense), mainly in spring tide period (Figs. 4 and 5a, d, e). This asymmetry behavior for the ebb tide in Vitória Bay was also noticed in other local works involving in situ modeling and measurements (Rigo, 2004; Moura et al., 2011).

The tidal currents are regulated mainly by the bathymetry, the morphology, the near-bottom friction and by the Coriolis effect (Miranda et al., 2002). The existence of tidal flats and mangroves in BV has been considered by Rigo (2004) as fundamental for the occurrence of the ebb tide asymmetry. The tidal flat and mangrove areas can store large quantities of water in relation to the main channel. Thus, the tide propagates chiefly in the deeper channels near the low tide, resulting in a longer duration for flood tide than for ebb tide and in stronger ebb tide currents (Dronkers, 1986). The studies carried out by Rigo (2004) indicated a 45\% increase of the current velocities when the BV tidal flat effect was considered in the used models. The effect of these tidal flats in asymmetry would be stronger during the spring tides as a function of the larger tide amplitude in the estuary. The presence of mangrove vegetation in the tidal flats also helps delaying the flow of water, contributing to the tidal distortion in the estuarine regions (Wolanski et al., 1990; Rigo, 2004).

It was also noticed at P2 that the current direction changes completely in the entire water column during one tidal cycle. The currents are orientated mainly to northeast and east in the ebb tide and to west in the flood tide. However, there is a temporal dominance of the flood tidal currents near the bottom and of the ebb tidal currents near the surface (Fig. 4).

Figure $5 f$ shows that larger concentrations of SPM (turbidity) occur near the bottom during ebb tide in spring tide. However, a significant variation during the measurements period was not observed.

Figures $5 b, c$ shows the absence of waves in P2 and a strong influence of the tidal cycles on the sediment transport rates, prevailing the bedload transport. The bedload sediment transport rates show that this type of transport occurs only during the spring tide, when the ebb and flood tides are stronger. The transport peaks occur during the ebb tide towards the mouth of the estuary. Thus, the resulting bedload sediment transport direction and rate for the entire measurements period were $78.29^{\circ}$ and $0.000223 \mathrm{~kg} / \mathrm{s} / \mathrm{m}$, respectively, supporting the conclusion that at P2 BV bedload sediment would be exported (Figs. $5 \mathrm{~g}, \mathrm{~h}$ ).

\section{CONCLUSION}

Vitória coastal region has a variety of different environments, such as estuaries, channels and embayments, each one with remarkable characteristics in terms of hydrodynamics and sediment transport. Besides, the circulation can vary periodically due to 


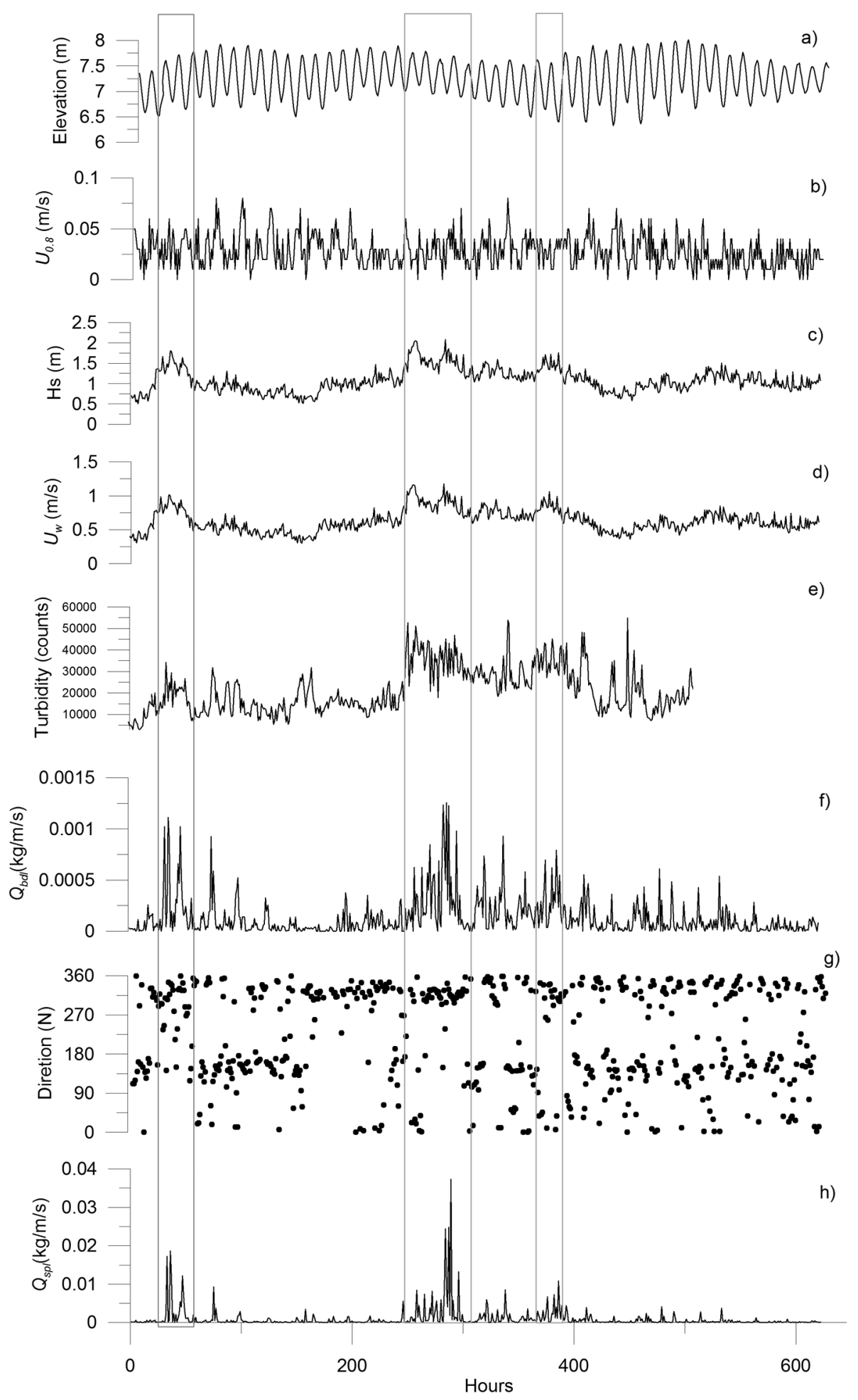

Figure 3 - ADP data measured in Espírito Santo Bay from June 15 to July 11, 2008: a) tidal elevation in meters; b) current velocity at $0.8 \mathrm{~m}$ from the bottom; c) wave height $(\mathrm{m})$; d) wave orbital velocity; e) turbidity (OBS - optical backscatter sensor) (SPM) at $0.8 \mathrm{~m}$ from the bottom (counts); f) bedload sediment transport rate $(\mathrm{kg} / \mathrm{m} / \mathrm{s}) ; \mathrm{g}$ ) bedload sediment transport direction; h) suspended particulate matter transport rate $(\mathrm{kg} / \mathrm{m} / \mathrm{s})$. The gray rectangles indicate the three cold front events measured during the measurement period. An increase in wave height followed by a turbidity and transport rate increase is observed. 

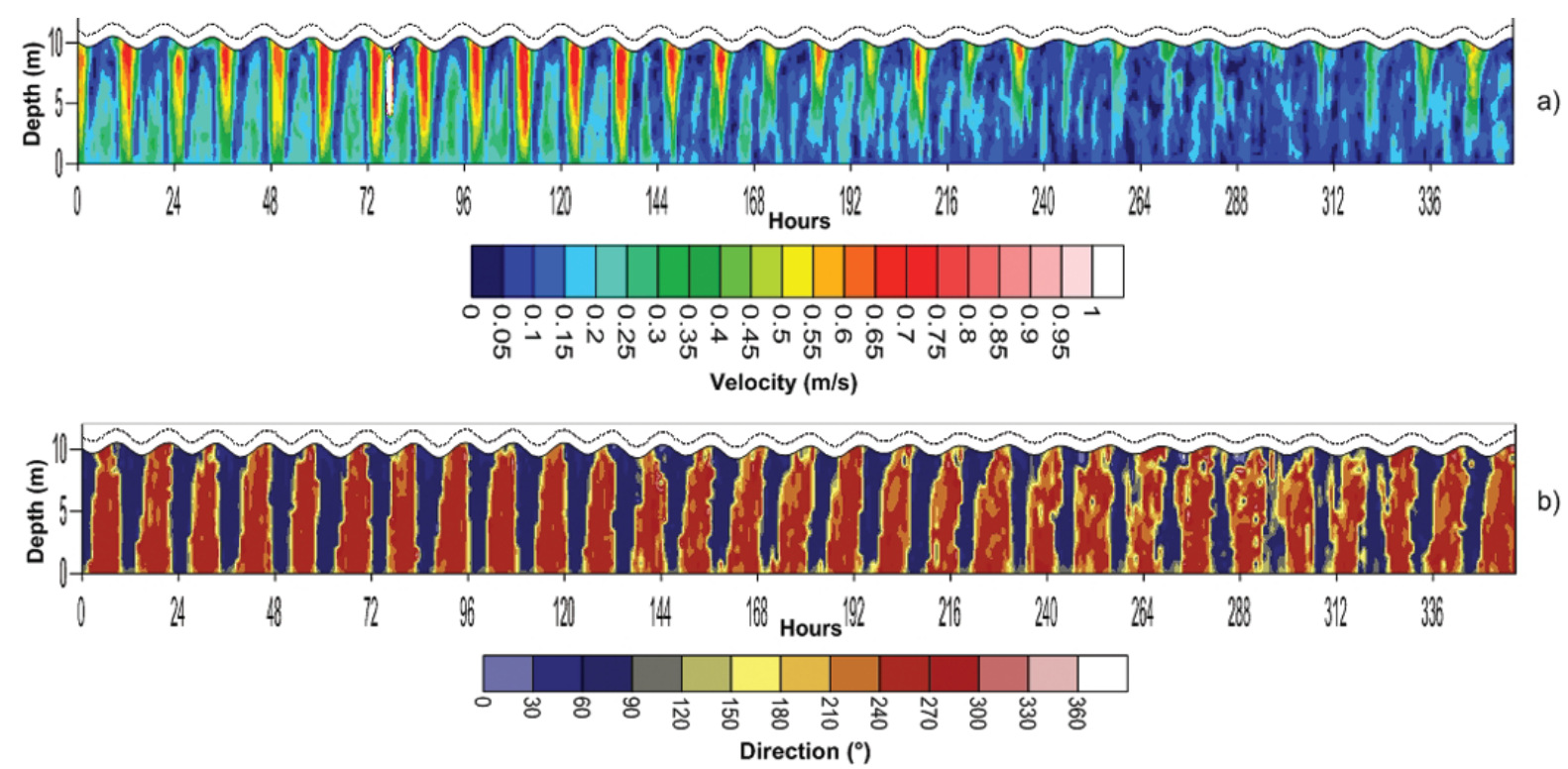

Figure 4 - Currents temporal series at P2 in Vitória Bay: a) velocity; b) direction.

the tidal cycles and/or the passage of cold fronts, just to cite some of the influencing factors.

A characteristic that notably distinguishes the two environments (BES and BV) is the influence on the circulation pattern during the passage of cold fronts. In BES, the circulation results from the interaction of waves, tides, currents and anthropogenic actions (existence of harbor and breakwater to avoid erosion) and does not show dominance of ebb or flood tide. However, the influence of more energetic waves, related to the cold fronts, in the sediment remobilization and transport process is very typical. It is observed in BES that the bedload and suspended transport rates are much higher (around $0.04 \mathrm{~kg} / \mathrm{m} / \mathrm{s}$ maximum) than the rates recorded and modeled for $B V(0.01 \mathrm{~kg} / \mathrm{m} / \mathrm{s}$ maximum). Estuarine circulation characteristics, prevailing the ebb tide, occurs at BV mooring site, without an immediate response to the cold fronts.

We can conclude that the main controlling mechanism for this difference in the behavior is the morphology of the two environments. BES, an open embayment towards the adjacent platform, is exposed to storm waves that enter in the Bay with intense energy, causing sediment resuspension and its consequent transport through the resulting currents (smaller than $0.2 \mathrm{~m} / \mathrm{s}$ ). BV presents a narrow channel well protected from the storm wave action and dominated by the tidal currents, which were not faster than $0.7-0.8 \mathrm{~m} / \mathrm{s}$ even in the spring tide. In this case, the highest sediment transport rates were related to the bedload transport during spring tides associated to the current friction near the bottom, mainly during the ebb tide.

\section{ACKNOWLEDGMENTS}

The research had financial support and resources from the Vitória City Fundação de Amparo à Ciência e à Tecnologia (Facitec) and received data from Vitória Harbour/CODESA. The first author was a scholarship student at the PIBIC Program at Facitec (Universidade Federal do Espírito Santo - UFES).

\section{REFERENCES}

ALBINO J, OLIVEIRA R, MAIA LP \& ALENCASTRE K. 2001. Processos atuais de sedimentação marinha e praial do litoral de Vitória, ES. Relatório Final da pesquisa, Fundo de Amparo à Ciência e à Tecnologia (FACITEC) - Prefeitura de Vitória, nº 198.2506/2000.

BAGNOLD RA. 1963. Mechanics of marine sedimentation. In: HILL MN (Ed.). The Sea, vol. 3, Wiley-Interscience, New York, p. 507-527.

BASTOS AC, PAPHITIS D \& COLLINS MB. 2004. Short-Term Dynamics and Maintenance Processes of Headland-Associated Sandbanks: Shambles Bank, English Channel, UK. Estuarine, Coastal and Shelf Science, 59: 33-47.

BROWN CB. 1950. Sediment transportation. In: ROUSE H (Ed.). Engineering Hydraulics, Wiley, New York, p. 769-857.

CARMO DA. 2009. Mapeamento faciológico do fundo marinho como ferramenta ao entendimento da dinâmica sedimentar da Baía do Espírito Santo, Vitória-ES. M.Sc. Dissertation, Postgraduate Program in Marine Geology and Geophysics, Universidade Federal Fluminense. 134 pp.

DONATELLI MR. 1998. Modelagem Matemática da Hidrodinâmica e da Qualidade da Água da Baía de Vitória. M.Sc. Dissertation, Postgraduate 


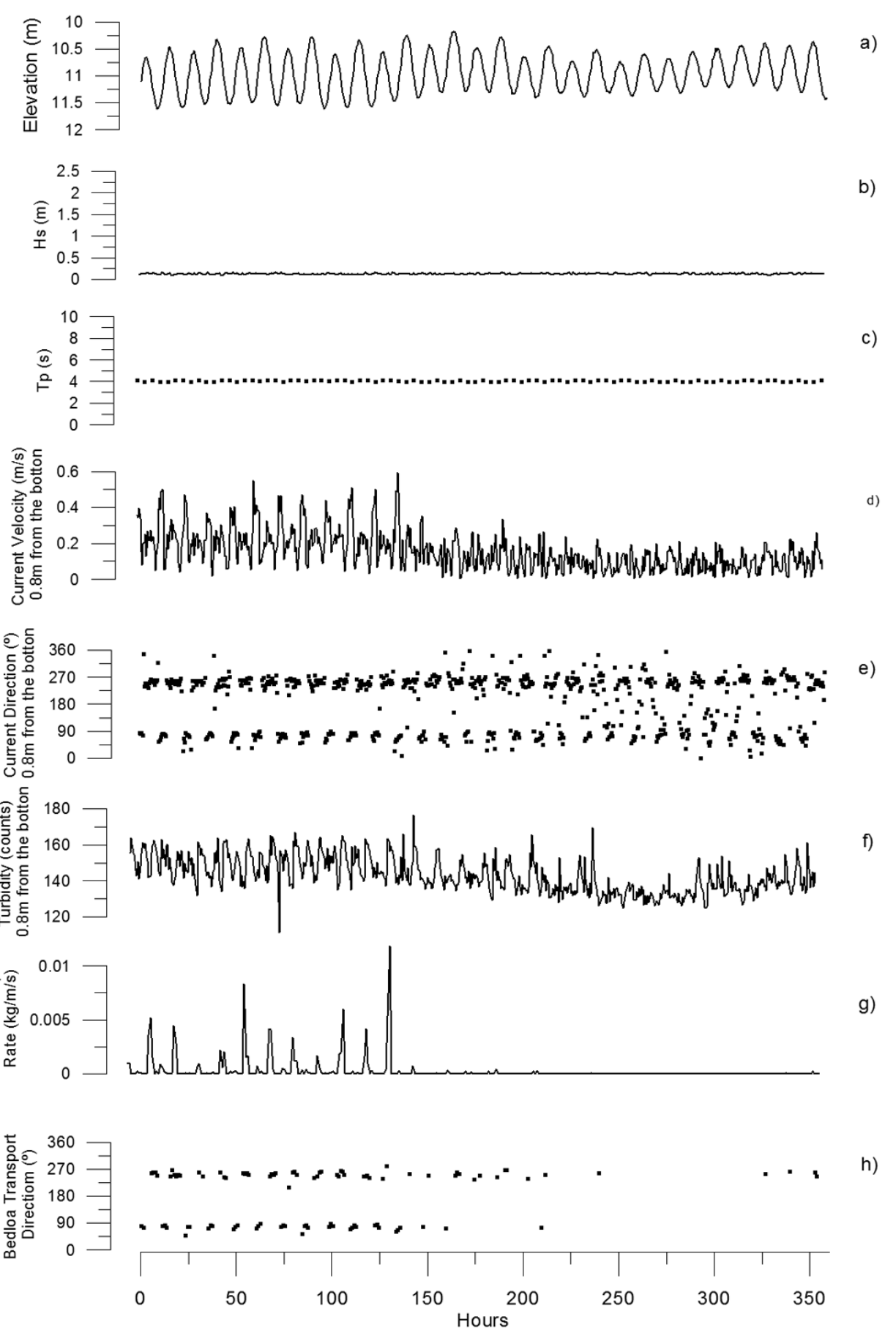

Figure 5 - ADP data measured in Vitória Bay at P2 from June 04 to June 19, 2009: a) tidal elevation in meters; b) wave height $(\mathrm{m})$; c) wave period (s); d) current velocity at $0.8 \mathrm{~m}$ from the bottom; e) tide current direction; $\mathrm{f}$ ) turbidity (OBS - optical backscatter sensor) at $0.8 \mathrm{~m}$ from the bottom (counts); $\mathrm{g}$ ) bedload sediment transport rate $(\mathrm{kg} / \mathrm{m} / \mathrm{s}) ; \mathrm{h}$ ) bedload sediment transport direction.

Program in Environmental Engineering, UFES, Vitória, Brasil. 192 pp. DRONKERS J. 1986. Tidal Asymmetry and Estuarine Morphology. Netherlands Journal of Sea Research, 20(2/3): 117-131.

DYER KR. 1997. Estuaries: A Physical Introduction. $2^{\text {nd }}$ ed., Chichester,
John Wiley \& Sons, $195 \mathrm{pp}$.

ENGELUND F \& HANSEN E. 1967. A Monograph on Sediment Transport in Alluvial Streams. Teknisk Vorlag, Copenhagen, 62 pp.

FAIRBRIDGE RW. 1980. The estuary: its definition and geodynamic cy- 
cle. In: OLAUSSON E \& CATO I (Ed.). Chemistry and Biogeochemistry of Estuaries. Wiley, New York, pp. 1-35.

FORTUNATO AB \& OLIVEIRA A. 2005. Influence of Intertidal Flats on Tidal Asymmetry. Journal of Coastal Research, 21(5): 1062-1067.

LI MZ, AMOS CL \& HEFFLER DE. 1997. Boundary Layer Dynamics and Sediment Transport under Storm and Non-Storm Conditions on the Scotian Shelf. Marine Geology, Dartmouth, 141: 157-181.

MARTINS GJ, MARONE E, ANGULO RJ, NOERNBERG MA \& QUADROS CJL. 2004. Dinâmica da zona de rasa de shoaling e o transporte de sedimentos na desembocadura sul do complexo estuarino de Paranaguá PR. Boletim Paranaense de Geociências, 54: 51-64.

MAZDA Y, KANAZAWA N \& WOLANSKI E. 1995. Tidal Asymmetry in Mangrove Creeks. Hydrobiologia, 295: 51-58.

MIRANDA LB, CASTRO BM \& KJERFVE B. 2002. Princípios de Oceanografia Física de estuários. São Paulo, EDUSP, 411 pp.

MOURA MG, QUARESMA VS, BASTOS AC \& VERONEZ Jr P. 2011. Field observations of SPM using ADV, ADP, and OBS in a shallow estuarine system with low SPM concentration Vitória Bay, SE Brazil. Ocean Dynamics, 61: 273-283.

NEUMEIER U, FERRARIN C, AMOS CL, UMGIESSER G \& LI MZ. 2008. Sedtrans05: An improved sediment-transport model for continental shelves and coastal waters with a new algorithm for cohesive sediments. Computer \& Geosciences, 34(10): 1223-1242.

PAPHITIS D \& COLLINS MB. 2005. Sediment resuspension events within the (microtidal) coastal waters of Thermaikos Gulf, northern Greece. Continental Shelf Research, 25: 2350-2365.

PEPPER DA \& STONE GW. 2004. Hydrodynamic and sedimentary re- sponses to two contrasting winter storms on the inner shelf of the northern Gulf of Mexico. Marine Geology, 210: 43-62.

RIGO D. 2004. Análise do escoamento em regiões estuarinas com manguezais - medições e modelagem na Baía de Vitória, ES. Doctorate Thesis, Postgraduate Program in Oceanic Engineering, COPPE, UFRJ, Rio de Janeiro. 140 pp.

SOULSBY RL. 1997. Dynamics of marine sands. London, Thomas Telford, $249 \mathrm{pp}$.

SPEER PE \& AUBREY DG. 1985. A Study of Non-Linear Tidal Propagation in Shallow Inlet/Estuarine Systems. Part II: Theory, Estuarine, Coastal and Shelf Science, 21: 207-224.

VAN RIJN LC. 1993. Principles of Sediment Transport in Rivers, Estuaries and Coastal Seas. Aqua Publications, Amsterdam. 650 pp.

VERONEZ Jr P, BASTOS AC \& QUARESMA VS. 2009. Morfologia e distribuição sedimentar em um sistema estuarino tropical: Baía de Vitória, ES. Revista Brasileira de Geofísica, 27(4): 609-624.

WANG ZB, JEUKEN MCJL, GERRITSEN H, DE VRIES HJ \& KORNMAN BA. 2002. Morphology and asymmetry of the vertical tide in the Westerscheld estuary. Continental Shelf Research, 22: 2599-2609.

WOLANSKI E, JONES M \& BUNT JS. 1980. Hydrodynamics of a Tidal Creek - Mangrove Swamp System. Australian Journal of Marine and Freshwater Research, 31: 431-450.

WOLANSKI E, MAZDA Y, KING B \& GAY S. 1990. Dynamics, Flushing and Trapping in Hinchinbrook Channel, a Giant Mangrove Swamp, Australia. Estuarine, Coastal and Shelf Science, 31: 555-579.

YALIN MS. 1963. An expression for bedload transportation. Journal of the Hydraulics Division, Proceedings of ASCE, 89(HY3): 221-250.

\section{NOTES ABOUT THE AUTHORS}

Rafael Carvalho Neves. Undergraduate in Oceanography at Universidade Federal do Espírito Santo (UFES); M.Sc. student at the post-graduate program in Environmental Oceanography (UFES); Junior Oceanographer at UMISAN - Hidrografia e Engenharia. Activity area: marine geophysics.

Valéria da Silva Quaresma. Undergraduate in Geography at Universidade Federal Fluminense (UFF, 1992); M.Sc. in Marine Geology and Geophysics at UFF Marine Geology Laboratory (1997); Doctorate degree in Geological Oceanography from the University of Southampton (2004); Adjunct professor at Universidade Federal do Espirito Santo (UFES) since 2006, participating at the post-graduate program in Environmental Oceanography (UFES). Activity area: sedimentary dynamics and high resolution applied geophysics.

Alex Cardoso Bastos. Undergraduate in Geology at Universidade Federal do Rio de Janeiro (UFRJ, 1993); M.Sc. in Marine Geology and Geophysics at Universidade Federal Fluminense (UFF, 1997); Doctorate degree in Sedimentary dynamics from the University of Southampton (2002); Post-Doctorate research in High Resolution Geophysics at the National Oceanography Center, UK. Presently is a professor at Universidade Federal do Espírito Santo (UFES), participating at the post-graduate program in Environmental Oceanography (UFES) and Marine Geology and Geophysics (UFF). Activity area: geological oceanography, marine geophysics and sedimentation.

Júlio César Ruano da Silva. Expert in Ecology and Natural Resources; Master degree in Environmental Engineering. Presently is a Doctorate Student at the postgraduate program in Environmental Oceanography (UFES). 